OPEN ACCESS

Edited by:

André Frainer,

Norwegian Institute for Nature

Research (NINA), Norway

Reviewed by:

Natalia Roos,

Federal University of Rio Grande do

Norte, Brazil

Charalampos Dimitriadis,

National Marine Park of Zakynthos,

Greece

${ }^{*}$ Correspondence:

Ella-Kari Muh

emuhl@uwaterloo.ca

Specialty section:

This article was submitted to

Marine Conservation

and Sustainability,

a section of the journal

Frontiers in Marine Science

Received: 28 March 2020

Accepted: 09 July 2020

Published: 29 July 2020

Citation:

Muhl E-K, Esteves Dias AC and Armitage $D$ (2020) Experiences With

Governance in Three Marine

Conservation Zoning Initiatives:

Parameters for Assessment

and Pathways Forward.

Front. Mar. Sci. 7:629.

doi: 10.3389/fmars.2020.00629

\section{Experiences With Governance in Three Marine Conservation Zoning Initiatives: Parameters for Assessment and Pathways Forward}

\author{
Ella-Kari Muhl*, Ana Carolina Esteves Dias and Derek Armitage \\ Environmental Change and Governance Group, School of Environment, Resources and Sustainability (SERS), Faculty \\ of Environment, University of Waterloo, Waterloo, ON, Canada
}

In this perspective paper, we examine the challenges of governance in three marine conservation settings where rights, access to resources and zoning intersect with changing social and ecological conditions: (1) Tsitsikamma Marine Protected Area in South Africa; (2) Marine Protected Area of the Northern Coast of São Paulo (APAMLN) in Brazil; and (3) Gwaii Haanas National Marine Conservation Area Reserve in Canada. Many MPAs and related zoning initiatives are located adjacent to coastal communities that rely on marine and coastal resources for their livelihoods. Thus, processes of zoning must often address local use of natural resources which can be perceived by decisionmakers and regulators as problematic. Our analysis highlights how conservation zoning intersects with the perception of diverse stakeholders regarding a range of governance dimensions, including: (1) levels of participation and compliance; (2) the clarity of zoning and conservation objectives; (3) livelihood impacts and benefits; (4) evidence of ecological and conservation benefits; and (5) the influence on sense of place. Pathways forward to address the challenges of governance associated with zoning include the importance of co-producing knowledge for more robust zoning outcomes, and situating zoning processes in a co-management context in which power and authority are more evenly distributed.

Keywords: marine protected areas, zoning, governance, perceptions, rights

\section{PROBLEM CONTEXT AND CONCEPTUAL OVERVIEW}

Globally, marine protected areas (MPAs) are an established strategy to conserve the biodiversity and habitats associated with oceans and coasts (Jones, 2014; Day et al., 2019). Such strategies are important as nations aim to meet the Aichi targets and those that will emerge in the post-2020 Global Biodiversity Framework (Visconti et al., 2019). There are a variety of MPA categories, most of which have different levels of regulation to define the rules for access and multiple use zones (see IUCN categories and their management objectives - Dudley, 2008). How we evaluate the effectiveness of these conservation initiatives and zoning strategies with reference to both social and ecological outcomes is an important challenge for all MPA categories (Berkes, 2010; Ban et al., 2013; Sowman and Sunde, 2018; Naidoo et al., 2019). Zoning is a spatial planning process for marine protected areas and conservation efforts generally, and observations about their efficacy 
are crucial to long term success (Charles and Wilson, 2009). Here, we refer to zoning as the process of spatially delineating which actors and stakeholder groups have rights to access a marine area and its resources, guided by the normative goal of sustainability (Day et al., 2019).

We draw attention to issues of MPA governance literature and practice in several ways. Our analysis draws attention to issues of participation - who is involved and how, and the critical role of perceptions of those engaged in or affected by zoning initiatives (Mascia, 2004; Cinner et al., 2009; Pollnac and Seara, 2011; Di Ciommo and Schiavetti, 2012; Voyer et al., 2012; Bennett et al., 2020). We also discuss the implications of zoning for the individuals and/or communities that access or interact with valued ecological habitats (Villa et al., 2002; Gurney et al., 2016; McNeill et al., 2018). Understanding how different groups use and rely on an area for their livelihoods and cultural needs is particularly important in countries that have high levels of poverty, unemployment and food insecurity (Jones et al., 2017). The social impacts from creating an MPA, for example, that do not adequately consider adjacent community needs and rights, nor effectively engage them in the process of zone development, will further exacerbate situations in developing countries where limited capacity undermines governance processes and where there is a high level of dependence on natural resources (World Bank, 2017; McNeill et al., 2018). As a result, zoning interventions are often contested with regard to their socioeconomic and ecological objectives (Bennett and Dearden, 2014; Voyer et al., 2014; Ban et al., 2019), with implications for the success of marine protected area networks and conservation outcomes.

Assessing the effectiveness of marine protected areas and conservation initiatives has a long history (Bennett and Dearden, 2014; Larrosa et al., 2016). For example, Pomeroy et al. (2005) developed a framework to evaluate MPAs that includes a range of socio-economic, biophysical and governance criteria. Similarly, Jones et al. (2013) focused on the role of institutional "incentives" as important evaluative criteria drawing attention to the economic, interpretative, legal, knowledge and participative dimensions of marine conservation. Bennett and Dearden (2014), in contrast, have emphasized the importance of governance attributes as a way to understand MPA effectiveness, such as enabling policies, setting clear targets and objectives, fostering participation and relationships, adequately addressing capacity for participation, and providing appropriate tenure and rights over resources and ecosystems. Further, Gill et al. (2017) and Scianna et al. (2019) have emphasized that effective and equitable management of MPAs requires adequate staff and budget capacity for compliance and ecological success.

We outline a general framework for our assessment of zoning interventions and governance challenges across our case study sites (Table 1). Specifically, this framework synthesizes key insights from the literature that are relevant for our cases, and that allow us to draw lessons from different social-economic and governance contexts, highlighting some key commonalities and insights that may inform other practices and experiences.

\section{LEARNING FROM THE FIELD}

We analyze three case studies that reflect different issues with governance, drawing attention to who is involved and how the respective zoning initiatives are implemented (see Table 2). These cases studies were chosen opportunistically and reflect our experience in different geographic settings. However, a key criteria in selecting the cases is the potential to show variation of opportunities and challenges across different governance regimes, zoning types, and policy and socio-economic settings. Further, our analysis draws on data that has been generated from a wide range of semi-structured interviews with key stakeholders (community, government, management authority, and non-government), focus groups and workshops with diverse stakeholders and reviews of relevant literature (see for example Muhl, 2016, 2019; Berdej et al., 2017; Dias and Armitage, in press). We draw in particular on perceptions of those directly involved in these cases, noting that the perceptions of zoning by local people affect their levels of support and the legitimacy of the conservation initiative. We address each of the cases in turn.

\section{Marine Protected Area of the Northern Coast of São Paulo (APAMLN) - Brazil}

The marine protected area from the northern coast of São Paulo State (APAMLN) in Brazil is a state-level MPA created in 2008

TABLE 1 | Framework for comparative assessment of zoning and governance outcomes.

\begin{tabular}{|c|c|}
\hline Key parameter & Selected issues related to zoning \\
\hline \multirow[t]{3}{*}{$\begin{array}{l}\text { Participation, collaboration } \\
\text { and compliance }\end{array}$} & $\begin{array}{l}\text { - Level of or presence/absence of meaningful } \\
\text { participation and engagement }\end{array}$ \\
\hline & $\begin{array}{l}\text { - Regulated as well as informal opportunities for } \\
\text { participation and engagement }\end{array}$ \\
\hline & - Clarity of roles of different stakeholders \\
\hline \multirow[t]{4}{*}{ Clarity of objectives } & $\begin{array}{l}\text { - Emphasis on social and economic as well as } \\
\text { ecological objectives }\end{array}$ \\
\hline & - Communication of objectives to stakeholders \\
\hline & $\begin{array}{l}\text { - Relationships among objectives and guiding } \\
\text { principles for conservation }\end{array}$ \\
\hline & - Synergy among objectives \\
\hline \multirow[t]{2}{*}{ Livelihood benefits } & $\begin{array}{l}\text { - Implications of zoning for stakeholders in terms of } \\
\text { access and resources needed for livelihoods }\end{array}$ \\
\hline & $\begin{array}{l}\text { - Consideration of differential livelihood implications } \\
\text { for different groups (e.g., Indigenous, } \\
\text { non-Indigenous) }\end{array}$ \\
\hline \multirow[t]{2}{*}{$\begin{array}{l}\text { Ecological and } \\
\text { conservation benefits }\end{array}$} & $\begin{array}{l}\text { - Clear evidence of ecological benefits, outcomes } \\
\text { from zoning (habitat, species protection) }\end{array}$ \\
\hline & $\begin{array}{l}\text { - Incorporation of ecological knowledge of diverse } \\
\text { groups in clarifying conditions (e.g., increase, } \\
\text { decrease in stocks) }\end{array}$ \\
\hline \multirow[t]{3}{*}{ Sense of place } & $\begin{array}{l}\text { - Implications of zoning on maintaining, disrupting } \\
\text { place attachment }\end{array}$ \\
\hline & $\begin{array}{l}\text { - Recognition of identity of adjacent communities to } \\
\text { spaces, places subject to zoning }\end{array}$ \\
\hline & $\begin{array}{l}\text { - Potential influence of zoning and regulatory } \\
\text { requirements on place, culture and customary } \\
\text { resource practices (e.g., sharing) }\end{array}$ \\
\hline
\end{tabular}


TABLE 2 | Overview of case study areas.

\begin{tabular}{|c|c|c|c|}
\hline & $\begin{array}{l}\text { Marine protected area of the northern } \\
\text { coast of São Paulo (APAMLN) }\end{array}$ & Gwaii Haanas & Tsitsikamma \\
\hline IUCN category & $\begin{array}{l}\text { VI: Protected area with sustainable use of } \\
\text { natural resources }\end{array}$ & V: Protected Landscape/Seascape & II: National Park \\
\hline $\begin{array}{l}\text { Size of area, } \\
\text { location }\end{array}$ & $\begin{array}{l}\text { Situated in the northern portion of the coast } \\
\text { of São Paulo, Brazil with a total area of } \\
3,160 \mathrm{~km}^{2}\end{array}$ & $\begin{array}{l}\text { Situated at the southern end of Haida } \\
\text { Gwaii, an archipelago off the north pacific } \\
\text { coast of Canada, with a total area of } \\
5,000 \mathrm{~km}^{2}\end{array}$ & $\begin{array}{l}\text { Situated on the border of the Western and } \\
\text { Eastern Cape Provinces in southern } \\
\text { South Africa, with a total area of } 186 \mathrm{~km}^{2}\end{array}$ \\
\hline $\begin{array}{l}\text { Socio- economic } \\
\text { features }\end{array}$ & $\begin{array}{l}\text { Ubatuba, Caraguatatuba, Ilhabella and São } \\
\text { Sebastião: } 320,000 \text { inhabitants with } \\
\text { 300-1,500 additional inhabitants along the } \\
\text { coast Local livelihoods based on } \\
\text { small-scale fisheries and tourism. }\end{array}$ & $\begin{array}{l}\text { Haida Gwaii: 4,320 inhabitants Gwaii } \\
\text { Haanas is important for fishing, Haida } \\
\text { traditional use, education and tourism. }\end{array}$ & $\begin{array}{l}\text { Koukamma municipality: } 40,663 \\
\text { inhabitants. Average household income is } \\
\text { between USD1384 to USD2697 per month. } \\
\text { Unemployment in the area is at } 50 \% \text {. } \\
\text { Reliance on natural resources }\end{array}$ \\
\hline $\begin{array}{l}\text { Responsible } \\
\text { authority and } \\
\text { governance context }\end{array}$ & $\begin{array}{l}\text { State government: Manager in-chief }+ \\
\text { management council ( } 50 \% \text { Civil society, } \\
50 \% \text { governmental organizations) }\end{array}$ & $\begin{array}{l}\text { Archipelago Management Board (AMB) } \\
\text { with equal representation from the Haida } \\
\text { Nation and DFO and Parks Canada. }\end{array}$ & $\begin{array}{l}\text { South African National Parks under the } \\
\text { Department of Environment, Forestry and } \\
\text { Fisheries (DEFF) }\end{array}$ \\
\hline $\begin{array}{l}\text { Information on } \\
\text { zoning / Zoning } \\
\text { types }\end{array}$ & $\begin{array}{l}\text { Five zones: small-scale (e.g., fisheries } \\
\text { coordinated with state and federal level } \\
\text { regulations on seasonal closures and gear } \\
\text { restriction), intensive and extensive use, a } \\
\text { no-take area and geobiodiversity protection } \\
\text { in which the extraction of natural resources } \\
\text { is not allowed, but other uses are (e.g., } \\
\text { maritime traffic, tourism). }\end{array}$ & $\begin{array}{l}\text { Three sectors: Restricted, strict protection } \\
\text { and multiple use. Haida traditional use } \\
\text { permitted in all zones. }\end{array}$ & $\begin{array}{l}\text { No-take }(80 \%) \text { with three coastal control } \\
\text { zones }(20 \%) \text { restricted to registered } \\
\text { community members only }\end{array}$ \\
\hline $\begin{array}{l}\text { Timeline/key } \\
\text { events, }\end{array}$ & $\begin{array}{l}2010 \text { - Participatory assessment to inform } \\
\text { management plan. } 2013 \text { - Process begins } \\
\text { to create MPA management plan } 2016 \text { - } \\
\text { Process halts } 2018 \text { - Zoning of the MPA - } \\
\text { ongoing with increasing participatory input. }\end{array}$ & $\begin{array}{l}1985 \text { - Gwaii Haanas declared a Heritage } \\
\text { Site by Haida Nation } 2010 \text { - Gwaii Haanas } \\
\text { Marine Agreement signed and Marine } \\
\text { Conservation Reserve established } 2014 \text { - } \\
\text { Process begins to create the } \\
\text { Land-Sea-People Management Plan 2018- } \\
\text { The Gwaii Haanas Land-Sea-People plan } \\
\text { implemented }\end{array}$ & $\begin{array}{l}1964 \text { - Proclamation of the Tsitsikamma } \\
\text { MPA } 1976 \text { - } 1978 \text { Fishing is reduced to a } \\
\text { three kilometer zone } 2000 \text { - MPA is } \\
\text { declared "no-take" } 2007,2015 \text { - Attempts } \\
\text { to rezone the park for controlled access for } \\
\text { local fishers } 2016 \text { - The MPA is rezoned to } \\
\text { have three controlled coastal zones for } \\
\text { fishing with strict regulations. }\end{array}$ \\
\hline
\end{tabular}

that encompasses the marine area of the northern coastal portion of the state of São Paulo. The region is characterized by a jagged coastline, including estuaries and mangroves, hundreds of sandy beaches, rocky shores and more than 40 coastal islands with a total area of $3,160 \mathrm{~km}^{2}$ (São Paulo, 2008). As a multiple use MPA (Brazil, 2000), it has a mandate to protect marine ecosystems and regulate human activities within the area. The rights of traditional peoples (i.e., the Caiçaras) to use natural resources and the territory is legally guaranteed. This MPA is divided into three marine and island sectors (Cunhambebe, Maembipe, and Alcatrazes), across four municipalities, making it challenging from a jurisdictional perspective.

Even though the MPA was created in 2008, it still lacks a management plan. The purpose of the MPA is to regulate economic (e.g., tourism, industrial fisheries, nautical infrastructure) and traditional activities (e.g., small-scale fisheries). A lack of financial resources and personnel, political instability and a history of conflict between environmental authorities and coastal communities has led to setbacks in implementation of the MPA. Additionally, reduced participation of coastal communities, and lack of clear goals and roles has further exacerbated issues with the management of the MPA.
In 2010, a process was initiated to assess key stakeholders, local uses of the marine area and other relevant information to inform the management plan and zoning of the MPA. Currently, a draft of the zoning plan is being discussed with stakeholders and it includes five zones. The zones are categorized as: smallscale, intensive and extensive use, geobiodiversity protection and "no-take" areas. Despite increased efforts to engage the community in the zoning process, participation has been low overall (especially among youth), despite the relevance of the changes to future livelihoods.

A current lack of legitimacy and accountability with regards to the zoning process is linked to a participatory plan that is frequently interrupted, highly dependent on political will and, in many situations, lacks resources to proceed effectively (see also Seixas and Berkes, 2004). The MPA is currently developing the management plan and zoning process. However, as of 2018, this process gained an important ally, a local movement comprised of Indigenous people (Traditional Peoples Forum - from Ubatuba, Paraty, and Angra dos Reis). Additionally, participatory processes in the region are being mediated by researchers, calling for accountability of stakeholders (Seixas et al., 2017). 


\section{Gwaii Haanas - Canada}

The Gwaii Haanas National Marine Conservation Area Reserve is situated at the southern end of Haida Gwaii, an archipelago off the north-pacific coast of Canada. Gwaii Haanas is 5000 square kilometers and is co-governed with reference to the Gwaii Haanas Gina Waadluxan KilGulGa (Talking about Everything) LandSea-People management plan (Council of the Haida Nation and Government of Canada, 2018).

The Gwaii Haanas area was originally designated in 1985 as a Haida heritage site by the Haida Nation. In 1987, the site was further designated a National Park by Canada and British Columbia through the South Moresby Memorandum of Understanding. The Gwaii Haanas Agreement was signed in 1993 and set the groundwork for co-management of the protected area through a partnership between the Haida Nation and the Government of Canada (Gwaii Haanas Agreement, 1993; Gwaii Haanas Marine Agreement, 2010).

The Gwaii Haanas National Marine Conservation Area Reserve is now co-governed through the Archipelago Management Board (AMB), which consists of three representatives from the Haida Nation and three representatives from the federal government (two from Parks Canada and one from the Department of Fisheries and Oceans Canada). The management plan was created in partnership and with support from a marine planning team from the Council of Haida Nation, Parks Canada and Fisheries and Oceans Canada technical staff, and involved extensive consultation over a 4 year period (Council of the Haida Nation and Government of Canada, 2018).

Gwaii Haanas is divided into multiple zones with different levels of protection. There are four terrestrial and three marine zones to protect ecological and cultural areas of importance while ensuring sustainable livelihoods. The three marine zones are designated as restricted access, strict protection and multiple use. Forty percent of the marine reserve is "strict protection" and "restricted access." "Restricted access" only allows for conditional research. "Strict protection" prohibits extractive activates, although boat access and anchoring for educational, tourism and recreational activities is permitted. The remainder of the marine zone is "multiple use" and allows for specific marine activities. Haida traditional use is permitted in all terrestrial and marine zones, consistent with the Constitution of the Haida Nation and section 35 of the Constitution Act (Canadian Constitution Act, 1982; Haida Nation Constitution, 2014). Gwaii Haanas is considered an important area for fishing, Haida traditional use, education and tourism, with an average of 2500-3000 people visiting per year (Council of the Haida Nation and Government of Canada, 2018).

From a governance perspective, the context for the Gwaii Haanas National Park Reserve is unique, and potentially wellsuited to deal with the complexity in the system. Specifically, the AMB sets the direction for how the Gwaii Haanas Management Plan will be applied to help manage the area from the mountain peaks to the seabed (including fisheries i.e., herring) as an interconnected ecosystem. Decisions are made on a consensus basis and are binding with the Haida Nation and the Crown having shared decision making power. The strength of the co-governance body can be seen in the joint Haida Nation-federal announcements, for example, to prohibit all "bottom contact" fishing in the marine reserve. Although challenges still exist, the management plan has set a positive and strong foundation for the future conservation of the area (Jones et al., 2017).

\section{Tsitsikamma - South Africa}

The Tsitsikamma National Park MPA stretches for 60 kilometers along the Western Indian Ocean. It has a rugged coastline with steep cliffs and sandy beaches. The Tsitsikamma MPA is managed by South African National Parks (SANParks), the conservation management authority, which is overseen by the Department of Environment, Forestry and Fisheries (DEFF).

The Tsitsikamma MPA was created in 1964 and is the oldest MPA in South Africa. In South Africa, MPAs created prior to 1994 under the Apartheid regime disregarded local communities' rights to the coast and in some cases removed or restricted access, with no consultation. Therefore the MPA has been disputed since its creation. The Tsitsikamma MPA was proclaimed a strict "no-take" zone from 2000 following the collapse of some South African line fishery stocks (Chadwick et al., 2014). However, the adjacent communities perceived the area as being closed from 1978 when most of the coastal area was zoned as closed for fishing and physical access, except for a small section of three kilometers, and with the rest of the park zoned as "no-take" (Muhl, 2016). Rezoning was attempted in 2007 and 2015, but was not successful because of ongoing stakeholder disputes.

In December 2016 the Tsitsikamma MPA was rezoned from a "no-take" MPA to a partially open protected area with the aim of finally addressing historical exclusion and to provide managed access and benefits to adjacent communities. The rezoning allows for managed access for recreational fishing only by local community members and only in three designated coastal control zones (20\% of the park) on specific days (four times a month) and according to a set of regulations (i.e., only certain species allowed to be caught, with set quotas) (DEAT Protected Areas Act No. 57 of 2003 Regulation 2016:40511). The remainder of the park $(80 \%)$ is a "no-take" MPA, with strict fines in place. To fish in the coastal control zones, community members must live in or adjacent to the MPA and register as anglers. They are required to have a standard recreational fishing permit and need to register as a Tsitsikamma community angler at the conservation management authority office (Protected Areas Act No. 57 of 2003 Regulation 2016:40511).

From a governance perspective the 2016 MPA rezoning process has been challenged because of the speed in which it took place and the lack of consultation. Marine and social scientists who had historically been involved in extensive research in the area, NGO representatives and vulnerable community members who had historic ties to the coast were not consulted and do not deem the open areas appropriate for fishing access. Additionally, the conservation management authority under instruction from the then Department of Environmental Affairs (now DEFF) had only 5 days to legally implement the rezoning initiative. As a result, the participation processes about the rezoning only engaged the leadership of the Tsitsikamma Angling Forum (TAF), a sub-set of anglers that is not representative of all subsistence 
angling interests. This lack of participation among diverse stakeholders has led to a range of issues and ongoing conflicts.

\section{ZONING, PERCEPTIONS AND THE CHALLENGE OF MARINE GOVERNANCE}

In the sections below, we assess how the zoning initiatives in these cases intersect with insights about their effectiveness and impact. We focus in particular on perceptions about zoning, and draw specific attention to issues of collaboration and participation, clarity of objectives associated with zoning, livelihood implications, local understanding surrounding conservation and ecological benefits, and the relationship among zoning changes and sense of place (Table $\mathbf{1}$ ).

\section{Participation, Collaboration and Compliance}

The manner in which coastal actors (e.g., fishers, tourism operators) participate in zoning processes, and their expectations about levels of engagement or collaboration, have a significant influence on their views of zoning impacts and effectiveness (see also Cvitanovic et al., 2014; Dehens and Fanning, 2018). Here we define engagement and collaboration as the participatory processes through which trust is developed among coastal actors and in ways that promote knowledge sharing for collective action. Collaboration and effective engagement requires participants who have knowledge of the marine space and who can contribute meaningfully to a zoning process that can address socio-economic and conservation goals (Voyer and Gladstone, 2017). In the context of MPAs and allied zoning initiatives, meaningful participation ultimately fosters equal power among stakeholders groups to ensure fairness and legitimacy (Bennett and Dearden, 2014).

In the APAMLN, for example, managers are attempting to engage fishing communities (including Indigenous fishing communities) that use the area to establish the zoning process. A key obstacle to effective participation, however, has been the inappropriate use of communication tools. For instance, MPA staff prepared a pilot zoning plan to receive input from fishers, but they made this plan only available via the host MPA website. This is an inappropriate context as many community members do not have internet access. The process of participation has faced other setbacks too, such as misunderstandings regarding which laws apply in the territory (such as national and state regulations) and what is regulated by the MPA (e.g., special zones for biodiversity conservation). Moreover, the MPA is governed by a manager in chief and a management council consisting of community representatives. However, the participation of the council is unclear. Specifically, it is not clear if the council participates in decision making, or whether it participates in a primarily consultative role only. In the zoning process, this uncertainty manifests in a lack of understanding about how much the input from fishers and other community actors will be considered after the consultation phase.

In the Tsitsikamma case, participation and consultation did not occur among stakeholder groups despite the importance of the decisions being made about zoning and access for adjacent communities. In fact, the exclusion of certain groups (e.g., community representatives from all villages) led to the rezoning being perceived by many as illegitimate, further compounding enforcement and compliance challenges. The complex history of the Tsitsikamma MPA (Table 2) and the creation of the MPA has meant that there is still "poaching" that occurs in the park as the rezoning has not been perceived as effective in addressing their livelihood needs. As is the case of many MPAs, Tsitsikamma included, compliance is difficult to assess as it has an element of subjectivity that requires critical reflection. For example, local fishers perceive themselves as rightly having customary access to the area while park authorities view local fishers as disregarding the law (and therefore poachers).

In the Gwaii Haanas case, the extended consultation period, collaboration across partners and equal power sharing among the Haida Nation and the Crown (i.e., federal government) within the AMB has led to a zoning arrangement that is generally accepted, enforced and regarded as legitimate. Of particular note, there were many commercial fishing interests that were effectively engaged in the zoning process despite the potential costs associated with reduced access to fisheries and other marine resources.

\section{Clarity of Objectives}

One of the critical challenges confronting marine conservation initiatives involves the effort to balance multiple objectives social, economic and ecological (Pomeroy et al., 2005; Jones, 2014). Most marine conservation efforts are initiated as an effort to meet ecological objectives (e.g., habitat protection, species protection), and yet there is often significant uncertainty among adjacent communities as to why those objectives are prioritized and how they might coexist with material needs and cultural objectives. For example, in Tsitsikamma, the objectives of the zoning process have long been a source of confusion, with limited information given to coastal communities and even fewer opportunities for communication and meaningful engagement with decision makers as noted above. As a result, local people do not understand or accept the conservation objectives of the zoning intervention, and perceive the managing authority as failing to account for their own needs (cultural, social, and economic).

This situation in the Tsitsikamma case stands in sharp contrast to Gwaii Haanas, where a set of guiding principles situated in Haida culture were used in conjunction with ecosystem-based management principles to inform the zoning consultation initiative. Specifically, these principles were used to guide goals, objectives and indicators for innovative use across both scientific and local knowledge practices to promote legitimacy. In the APAMLN, the experiences were more mixed. This MPA established five zones to define the activities permitted (see Table 2), and six "areas of interest," in which management programs for specific purposes (e.g., conservation, sustainable tourism) should be implemented. These zones and areas of interest are well described in the official documents; however, the rationale behind this arrangement has not been effectively discussed with those affected by them. Moreover, when 
establishing the zoning objectives for the MPA, state and federal laws that apply to fishing are still in place (e.g., seasonal closures of shrimp and mullet fishing, the banning of certain fishing gear). These overlapping regulatory arrangements reflect competing objectives and can enhance confusion as to what rules may be modified, and how they relate to different fisheries.

\section{Livelihood Benefits}

Zoning processes inevitably affect the livelihoods of individuals and communities, primarily in terms of access to resources (Sowman, 2015). How people experience these impacts has significant implications for the perceived legitimacy of zoning efforts in marine conservation initiatives. In Gwaii Haanas, for example, the zoning process is embedded in a broader effort to maintain traditional access to marine resources and in a manner that is consistent with the Constitution of the Haida Nation, and section 35 of the Constitution Act. As a result, the outcomes of the zoning process are generally viewed as positive and supportive of longer-term efforts to maintain the cultural connection Haida peoples have with the sea. The zoning process in the APAMLN is less clear in terms of the implications for livelihoods, as other laws and regulations also apply in the territory and may restrict access of small-scale fishers. Despite the fact that the APAMLN permits sustainable use, many fishers observe the zoning process as restricting their access to key fishing grounds. On the other hand, some community members, usually those more engaged in the MPA meetings, recognize opportunities to collaborate and to demonstrate their needs (e.g., in terms of gear or access to specific habitats). Arguably the most challenging situation emerges in the context of Tsitsikamma, where the implications of the loss of direct access to the coast for adjacent communities has been profound (Faasen and Watts, 2007). Many community members report a significant loss of livelihoods and an impact in food security (Muhl, 2016) which more recent rezoning efforts have failed to address (Muhl, 2019).

\section{Ecological and Conservation Benefits}

Marine conservation initiatives are typically aimed at protecting critical habitat, species of significant ecological value and/or representative ecosystems (Jones, 2014). Secondary ecological and conservation benefits may also include the preservation of contexts for scientific research. However, the extent to which these ecological and conservation benefits are achieved has much to do with the location and design of zoning efforts (Gurney et al., 2016). Perceptions of these zoning efforts and their ultimate ecological outcomes is therefore a critical dimension of governance effectiveness. For instance, the Tsitsikamma zoning process failed to incorporate the knowledge of local fishers about the status of stocks or levels of fishing effort, thus undermining the opportunity to clarify the conservation benefits behind the original zoning initiative. This failure to clarify the ecological and conservation benefits (given the livelihood impacts generated) was a fundamental reason why the rezoning was seen as unsuccessful, and it exacerbated feelings of mistrust of the managing authorities among local communities. In contrast, the process in Gwaii Haanas management has been more proactive in articulating the conservation and ecological benefits of zoning. Specifically, the zoning process has deliberately integrated conventional scientific understanding of ecological values with insights and local knowledge from the Haida people. This has led to zoning outcomes that reflect shared perspectives of what is ecologically valuable and of conservation importance, while respecting the cultural imperative of the Haida to harvest marine resources.

\section{Sense of Place}

How individuals and communities are impacted by marine conservation initiatives that are connected to places and spaces of importance will have significant implications for marine

TABLE 3 | Summary of key lessons learned.

\begin{tabular}{ll}
\hline Key dimension & Key lessons \\
\hline Participation, collaboration & - MPAs need to reflect the priorities of Indigenous \\
and compliance & and traditional communities, in addition to \\
& conservation objectives (i.e., zoning processes) \\
- Levels of participation not necessarily aligned with & good decision-making outcomes unless core \\
& social and economic outcomes are considered \\
- Collaboration and negotiated decision-making & across stakeholder groups (including youth) will \\
enhance legitimacy and thus lead to improved \\
governance outcomes
\end{tabular}

Clarity of objectives

- Public policy (e.g., overlapping protected area regulations) can confuse how people view the objectives of the protected area zoning

- Involving groups who will be affected by policy changes in negotiating, defining and implementing objectives will lead to increased understanding surrounding MPA zoning

Livelihood benefits

- MPA implications for local livelihoods need to be meaningfully considered by authorities, given the future implications of livelihood change among different stakeholder groups (e.g., youth)

- Collaboration round tables that enable communities and conservation authorities provide a basis to clarify and negotiate livelihood needs (e.g., in terms of gear or access to specific habitat zones)

Ecological and conservation benefits

- Conservation benefits are undermined if they fail to address the underlying socio-economic factors or provide alternate livelihood benefits in accordance with local norms

- Location and design of zoning efforts need to be cognisant and address conservation objectives associated with the original zoning initiative

Sense of place

- Place attachment is an important (but often overlooked) driver of perceptions different stakeholders may have about zoning processes

- Engaging fishers in community science (such as in monitoring critical places and spaces) and fostering Indigenous-led research can allow for shared recognition of conservation interventions and highlight connections to place engagement

- Enhancing and including local knowledge, and fostering local participation in tourism and resource management practices, can improve local sense of place and zoning outcomes 
conservation outcomes (Larson et al., 2013). In particular, the influence of zoning on place attachment - the emotional bonds formed between an individual and a geographic context can influence how people discern the effectiveness of marine conservation efforts and their willingness to collaborate in governance processes. Both in Brazil and in South Africa there is a strong sensitivity within the community that their identity is tied to the sea, and that the subsequent loss of access to the sea is akin to undermining their history as "people of the sea." For instance, in Brazil, the Caiçara people are a traditional group that inhabits the south and southeast coast of Brazil. Their traditional livelihoods are based on small-scale fisheries, smallscale agriculture and hunting (Diegues et al., 2000). Caiçara people also possess a strong sharing culture as expressed through their collaborative fishing practices and a strong attachment to the territory (Hanazaki et al., 1996). Yet, environmental regulations and restrictions in the use of resources in traditional territories are an issue in Brazil and has affected the zoning process in the APAMLN. This situation compounds the opinion of communities that traditional rights and place attachment were already undermined by the initial establishment of the MPA.

In South Africa, many community members have voiced a sense of loss of their identity and culture. The rise in crime rates and increased prevalence of substance abuse has also been attributed to the loss of access to the coastline as a result of the zoning process (Faasen, 2006; Williams, 2013; Muhl, 2016). In Gwaii Haanas, the management plan has been designed to maintain and foster a place connection between the Haida to their cultural and ecological heritage. Specifically, the management plan maintains access and allows for traditional use while ensuring long-term sustainable conservation for future generations.

\section{LESSONS LEARNED AND PATHWAYS FORWARD}

The expansion of marine protected areas (MPAs) and the zoning approaches associated with them generate diverse governance challenges. In this paper, we have analyzed the experiences with zoning in three unique case studies. From these different contexts, we have highlighted several commonalities and revealed pathways forward that may inform other practices and experiences in different contexts (Table 3). These lessons and pathways illustrate the influence of the socio-economic and policy contexts on perceptions about zoning, and ultimately, governance outcomes in MPAs.

As the lessons from these cases reveal, efforts to improve perceptions and long-term effectiveness of zoning will benefit from knowledge "co-production" and a participatory comanagement approach. First, a co-production process can be an effective mechanism to identify plausible and feasible zones, particularly in places where there may be more significant contestation. Such "co-produced zones" will have common agreements on achievements, and help to clarify what is being accomplished and how it is measured. However, we need to be cognisant of capacity issues and allocate appropriate time frames when "co-producing zones." In this regard, community science (i.e., increased collaboration and participation in research and monitoring - see Charles et al., 2016) can help to support co-production processes, especially where Indigenous groups and their knowledge can have a central role in zoning efforts (e.g., as in the example of Caiçara people in the Brazil case). Of note, engaging youth and addressing their perspectives on future livelihood opportunities provides an important pathway to move forward with regard to knowledge co-production and community science.

Second, a process to co-produce zoning arrangements will likely only work when power is effectively shared, as in the case of the AMB in Gwaii Haanas. Recommendations for improved co-management of MPAs are not novel, yet there remains a reticence to make the necessary shifts. Ceding decision making control in a way that equitably distributes power is an important precondition to improve zoning and is the basis for a transparent and collaborative process. As the case of the APAMLN shows, the lack of trust in decision-making criteria in upper governance levels, and lack of clarity on whether the management council has a consultative or deliberative role, causes mistrust and undermines collaboration with communities. Communities perceive and experience the lack of power in decision making (with consequences for their traditional territory or livelihoods), and this has negative long-term implications with regards to zoning initiatives.

\section{CONCLUSION}

The expansion of MPAs and other conservation measures in response to the post-2020 biodiversity conservation framework will generate diverse governance challenges. Examining the zoning processes associated with conservation and protection efforts is crucial as they influence the access and rights of communities adjacent to marine resources. We have highlighted in this perspective piece a suite of governance parameters around which stakeholders may perceive an array of challenges and opportunities with zoning, including levels of participation, clarity of objectives, impacts and benefits (ecological, livelihood) and sense of place. Moving forward, strategies to address these perceptions will require greater attention to processes of knowledge co-production and power-sharing to better ensure positive social and ecological outcomes.

\section{DATA AVAILABILITY STATEMENT}

The raw data supporting the conclusions of this article are protected for confidentiality purposes as per ethics agreements. Requests to access the datasets should be directed to the corresponding author.

\section{ETHICS STATEMENT}

The studies involving human participants were reviewed and approved by Faculty of Science Research Ethics Committee, 
University of Cape Town and Office of Research Ethics, University of Waterloo. The participants provided their informed consent to participate in this study.

\section{AUTHOR CONTRIBUTIONS}

E-KM coordinated this effort and contributed information for two of the three case studies. AE contributed information for one of the three case studies. DA edited and provided a high-level overview of the manuscript and critical guidance. All authors provided input, edited and contributed with text.

\section{REFERENCES}

Ban, N. C., Gurney, G. G., Marshall, N. A., Whitney, C. K., Mills, M., Gelcich, S., et al. (2019). Well-being outcomes of marine protected areas. Nat. Sustain. 2, 524-532.

Ban, N. C., Mills, M., Tam, J., Hicks, C. C., Klain, S., Stoeckl, N., et al. (2013). A social-ecological approach to conservation planning: embedding social considerations. Front. Ecol. Environ. 11:194-202. doi: 10.1890/110205

Bennett, N. J., Calò, A., Di Franco, A., Niccolini, F., Marzo, D., Domina, I., et al. (2020). Social equity and marine protected areas: perceptions of small-scale fishermen in the Mediterranean Sea. Biol. Conserv. 244:108531. doi: 10.1016/ j.biocon.2020.108531

Bennett, N. J., and Dearden, P. (2014). From measuring outcomes to providing inputs: governance, management, and local development for more effective marine protected areas. Mar. Policy 50, 96-110. doi: 10.1016/j.marpol.2014.05. 005

Berdej, S., Armitage, D., and Silver, J. (2017). Reflecting on Issues of Governance and Social-Ecological 'fit' in the Pacific Herring (Clupea pallasaii) fishery: Sitka, Alaska and Haida Gwaii, B.C. OceanCanada Partnership, Working Paper Series, Working Paper \#2017 - 2011. Vancouver, BC: Ocean Canada.

Berkes, F. (2010). Devolution of environment and resources governance: trends and future. Environ. Conserv. 37, 489-500. doi: 10.1017/s037689291000072x

Brazil (2000). Federal Law 9, 985 of July 18th, 2000. Establishes the National System of Protected Areas. Official Journal of the Union. Colombia: National System of Protected Areas.

Canadian Constitution Act (1982). The Constitution Act, 1982, Being Schedule B to the Canada Act 1982 (UK). Available online at: http://canlii.ca/t/ldsx (accessed March 26, 2020).

Chadwick, P., Duncan, J., and Tunley, K. (2014). State of Management of South Africa's Marine Protected Areas. Cape Town: WWF South Africa.

Charles, A., Westlund, L., Bartley, D. M., Fletcher, W. J., Garcia, S., Govan, H., et al. (2016). Fishing livelihoods as key to marine protected areas: insights from the World Parks Congress. Aquat. Conserv. 26, 165-184. doi: 10.1002/aqc.2648

Charles, A., and Wilson, L. (2009). Human dimensions of marine protected areas. ICES J. Mar. Sci. 66, 6-15. doi: 10.1093/icesjms/fsn182

Cinner, J., Fuentes, M. M. P. B., and Randiamahazo, H. (2009). Exploring social resilience in Madagascar's marine protected areas. Ecol. Soc. 14, 41-61.

Council of the Haida Nation and Government of Canada (2018). Council of the Haida Nation and Her Majesty the Queen in Right of Canada Gwaii Haanas Gina 'Waadluxan KilGuhlGa Land-Sea-People Management Plan. Skidegate, BC: Archipelago Management Board.

Cvitanovic, C., Marshall, N. A., Wilson, S. K., Dobbs, K., and Hobday, A. J. (2014). Perceptions of Australian marine protected area managers regarding the role, importance, and achievability of adaptation for managing the risks of climate change. Ecol. Soc. 19:33.

Day, J. C., Kenchington, R. A., Tanzer, J. M., and Cameron, D. S. (2019). Marine zoning revisited: how decades of zoning the great barrier reef has evolved as an effective spatial planning approach for marine ecosystem-based management. Aquat. Conserv. 29, 9-32. doi: 10.1002/aqc.3115

\section{FUNDING}

We acknowledge funding support from the Community Conservation Research Network and the Social Sciences and Humanities Research Council of Canada.

\section{ACKNOWLEDGMENTS}

We thank the communities in which we worked for their support and participation. This manuscript benefited from the constructive feedback and input of two referees. We also thank the IMBeR Interdisciplinary Marine Early Career Network (IMECaN) for initiating this special issue.

Dehens, L. A., and Fanning, L. M. (2018). What counts in making marine protected areas (MPAs) count? The role of legitimacy in MPA success in Canada. Ecol. Indic. 86, 45-57. doi: 10.1016/j.ecolind.2017.12.026

Di Ciommo, R. C., and Schiavetti, A. (2012). Women participation in the management of a marine protected area in Brazil. Ocean Coast. Manag. 62, 15-23. doi: 10.1016/j.ocecoaman.2012.02.010

Dias, A. C. E., and Armitage, D. (in press). "Using Photovoice to depict wellbeingecosystem services bundles for Marine Protected Areas governance," in Researching People and the Sea: Methodologies and Methods, eds M. Gustavsson and C. White. (Amsterdam: MARE Research).

Diegues, A. C., Arruda, R., da Silva, V., Figols, F., and Andrade, D. (2000). Os Saberes Tradicionais e a Biodiversidade no Brasil. São Paulo: NUPAUB-USP and MMA Press.

Dudley, N. (ed.) (2008). Guidelines for Applying Protected Area Management Categories. Gland: IUCN.

Faasen, H. (2006). Synergies Between Biodiversity Conservation and Sustainable Rural Development of Adjacent Communities: A case Study of the Tsitsikamma National Park, Unpublished M. Sc. Thesis, University of Stellenbosch, Stellenbosch.

Faasen, H., and Watts, S. (2007). Local community reaction to the 'no-take' policy on fishing in the Tsitsikamma National Park. South Africa. Ecol. Econ. 64, 36-46. doi: 10.1016/j.ecolecon.2007.06.026

Gill, D. A., Mascia, M. B., Ahmadia, G. N., Glew, L., Lester, S. E., Barnes, M., et al. (2017). Capacity shortfalls hinder the performance of marine protected areas globally. Nature 543, 665-669. doi: 10.1038/nature 21708

Gurney, G. G., Cinner, J. E., Sartin, J., Pressey, R. L., Ban, N. C., Marshall, N. A., et al. (2016). Participation in devolved commons management: multiscale socioeconomic factors related to individuals' participation in community-based management of marine protected areas in Indonesia. Environ. Sci. Pol. 61, 212-220. doi: 10.1016/j.envsci.2016.04.015

Gwaii Haanas Agreement (1993). Gwaii Haanas Agreement. Available online at: http://www.haidanation.ca/wp-content/uploads/2017/03/ GwaiiHaanasAgreement.pdf (accessed March 26, 2020).

Gwaii Haanas Marine Agreement (2010). Gwaii Haanas Marine Agreement. Available online at: https://www.pc.gc.ca/en/pn-np/bc/gwaiihaanas/info/coop/ / media/662F1B36258E462DA46C2E8372B62E3A.ashx (accessed March 26, 2020).

Haida Nation Constitution (2014). Constitution of the Haida Nation. Available online at: http://www.haidanation.ca/wp-content/uploads/2017/01/HaidaNation-Constitution.pdf (accessed March 26, 2020).

Hanazaki, N., de Freitas Leitão-Filho, H., and Begossi, A. (1996). Uso de recursos na Mata Atlântica: o caso da Ponta do Almada (Ubatuba, Brasil). Interciencia $21,268-276$.

Jones, P. J. (2014). Governing Marine Protected Areas: Resilience through Diversity. Abingdon: Routledge.

Jones, P. J. S., Qiu, W., and De Santo, E. M. (2013). Governing marine protected areas: social-ecological resilience through institutional diversity. Mar. Policy 41, 5-13. doi: 10.1016/j.marpol.2012.12.026 
Jones, R., Rigg, C., and Pinkerton, E. (2017). Strategies for assertion of conservation and local management rights: a haida gwaii herring story. Mar. Policy 80, 154-167. doi: 10.1016/j.marpol.2016.09.031

Larrosa, C., Carrasco, L. R., and Milner-Gulland, E. J. (2016). Unintended feedbacks: challenges and opportunities for improving conservation effectiveness. Conserv. Lett. 9, 316-326. doi: 10.1111/conl.12240

Larson, S., De Freitas, D. M., and Hicks, C. C. (2013). Sense of place as a determinant of people's attitudes towards the environment: implications for natural resources management and planning in the great barrier reef. Australia. J. Environ. Manage. 117, 226-234. doi: 10.1016/j.jenvman.2012.11.035

Mascia, M. B. (2004). "Social dimensions of marine reserves," in Marine Reserves: A Guide to Science, Design, and Use, eds J. Sobel and C. Dahlgren (Washington: Island Press), 164-186.

McNeill, A., Clifton, J., and Harvey, E. S. (2018). Attitudes to a marine protected area are associated with perceived social impacts. Mar. Policy 94, 106-118. doi: 10.1016/j.marpol.2018.04.020

Muhl, E. K. (2016). Food Security and Livelihood Threats: An Investigation into the Lives of the Fishers bordering the Tsitsikamma National Park, Honours Thesis, University of Cape Town, South Africa.

Muhl, E.-K. (2019). An analysis of the Perceptions Surrounding the re-Zoning of the Tsitsikamma Marine Protected Area. Unpublished MSc. Thesis, University of Cape Town, South Africa.

Naidoo, R., Gerkey, D., Hole, D., Pfaff, A., Ellis, A. M., Golden, C. D., et al. (2019). Evaluating the impacts of protected areas on human well-being across the developing world. Sci. Adv. 5:eaav3006. doi: 10.1126/sciadv.aav3006

Pollnac, R., and Seara, T. (2011). Factors influencing success of marine protected areas in the Visayas, Philippines as related to increasing protected area coverage. Environ. Manag. 47, 584-592. doi: 10.1007/s00267-010-9540-0

Pomeroy, R. S., Watson, L. M., Parks, J. E., and Cid, G. A. (2005). How is your MPA doing? A methodology for evaluating the management effectiveness of marine protected areas. Ocean Coast. Manag. 48, 485-502. doi: 10.1016/j.ocecoaman. 2005.05.004

São Paulo (2008). Provincial Decree 53,525 of October 8th, 2008. Creates the Marine Environmental Protected Area of the Northern Coast of São Paulo State and the Area of Relevant Ecological Interest of São Sebastião. Brazil: São Paulo.

Scianna, C., Niccolini, F., Giakoumi, S., Di Franco, A., Gaines, S. D., Bianchi, C. N., et al. (2019). Organization science improves management effectiveness of marine protected areas. J. Environ. Manage. 240, 285-292. doi: 10.1016/j. jenvman.2019.03.052

Seixas, C. S., and Berkes, F. (2004). "Stakeholder conflicts and solutions across political scales: The Ibiraquera Lagoon, Brazil," in Challenging Coasts: Transdisciplinary excursion into coastal zone development. MARE, ed. L. Visser (Amsterdam: Amsterdam University Press), 180-210.
Seixas, C. S., Dias, A. C. E., and de Freitas, R. (2017). Navigating from GovernmentCentralised Management to Adaptive co-Management in a Marine Protected area, Paraty, Brazil: Turbulence, Winds of Opportunity and Progress towards Transformation. In Governing the Coastal Commons. Abingdon: Routledge, 157-180.

Sowman, M. (2015). Governability Challenges Facing Small-Scale Fishers living Adjacent to Marine protected Areas in South Africa. In Interactive Governance for Small-Scale Fisheries. Cham: Springer, 359-377.

Sowman, M., and Sunde, J. (2018). Social impacts of marine protected areas in South Africa on coastal fishing communities. Ocean Coast. Manag. 157, 168-179. doi: 10.1016/j.ocecoaman.2018.02.013

Villa, F., Tunesi, L., and Agardy, T. (2002). Zoning marine protected areas through spatial multiple-criteria analysis: the case of the asinara island national marine reserve of italy. Conserv. Biol. 16, 515-526. doi: 10.1046/j.1523-1739.2002. 00425.x

Visconti, P., Butchart, S. H., Brooks, T. M., Langhammer, P. F., Marnewick, D., Vergara, S., et al. (2019). Protected area targets post-2020. Science 364, 239-241.

Voyer, M., and Gladstone, W. (2017). Human considerations in the use of marine protected areas for biodiversity conservation. Aust. Zool. 39, 173-180. doi: 10.7882/az.2015.029

Voyer, M., Gladstone, W., and Goodall, H. (2012). Methods of social assessment in Marine Protected Area planning: is public participation enough? Mar. Policy 36, 432-439. doi: 10.1016/j.marpol.2011.08.002

Voyer, M., Gladstone, W., and Goodall, H. (2014). Understanding marine park opposition: the relationship between social impacts, environmental knowledge and motivation to fish. Aquat. Conserv. 24, 441-462. doi: 10.1002/aqc. 2363

Williams, S. (2013). Beyond Rights: Developing a Conceptual Framework for Understanding Access to Coastal Resources at Ebenhaeser and Covie, Western Cape, South Africa. Thesis PhD, University of Cape Town, South Africa.

World Bank (2017). World Development Report: Governance and the Law. Washington, DC: WorldBank.

Conflict of Interest: The authors declare that the research was conducted in the absence of any commercial or financial relationships that could be construed as a potential conflict of interest.

Copyright (C) 2020 Muhl, Esteves Dias and Armitage. This is an open-access article distributed under the terms of the Creative Commons Attribution License (CC BY). The use, distribution or reproduction in other forums is permitted, provided the original author(s) and the copyright owner(s) are credited and that the original publication in this journal is cited, in accordance with accepted academic practice. No use, distribution or reproduction is permitted which does not comply with these terms. 